\title{
Stratégiát megalapozó elemzések gyakorlati alkalmazása
}

\section{Practical Application of Methods in Strategy-Based Analyzes}

\author{
MADAI H. ${ }^{1}$, BITTNER B. ${ }^{2}$, D. FOREST ${ }^{3}$, KOVÁCS T. Z. ${ }^{4}$, NAGY A. ${ }^{5}$, NÁBRÁDI A. ${ }^{6}$ \\ ${ }^{1}$ egyetemi adjunktus Debreceni Egyetem Gazdálkodástudományi Intézet, E-mail:madai.hainalka@econ.unideb.hu \\ ${ }^{2}$ egyetemi adjunktus Debreceni Egyetem Gazdálkodástudományi Intézet, E-mail:bittner.beata@econ.unideb.hu \\ ${ }^{3} \mathrm{PhD}$ hallgató Debreceni Egyetem Gazdálkodástudományi Intézet, E-mail:forestdavid5@gmail.com \\ ${ }^{4}$ PhD hallgató Debreceni Egyetem Gazdálkodástudományi Intézet, E-mail:kovacs.tunde.zita@econ.unideb.hu \\ ${ }^{5}$ egyetemi docens Debreceni Egyetem Gazdálkodástudományi Intézet, E-mail:nagy.adrian@econ.unideb.hu \\ ${ }^{6}$ egyetemi tanár Debreceni Egyetem Gazdálkodástudományi Intézet, E-mail:nabradi.andras@econ.unideb.hu
}

Absztrakt: A környezet növekvő változékonysága egyre nagyobb kihívást jelent a vállalatok, vállalkozások számára. A gazdasági események bekövetkezésének sebessége változó, a bizonytalanság miatti kockázat nő, ami az üzleti vállalkozásoktól új szemléletű tervezési gyakorlatot vár el. Stratégiájuk kialakitása, tervezése során mind a külső és a belső környezet tényezőinek feltárása, mind a versenytársaik elemzése jól megválasztott módszerek alapján történhet. Ezen módszerek áttekintését, a tervezési és oktatási gyakorlatban történő alkalmazását tekintjük cikkünk céljának, melynek során a hazai és a nemzetközi gyakorlatban is alkalmazott stratégiát megalapozó módszereket mutatjuk be, kiemelve a külső és a belső környezetet elemző módszereket. A külső környezet elemzése során a hagyományos PEST analízisre és a Porter-féle öttényezős modellre épülő külső faktor értékelö mátrix felépítését és alkalmazhatóságát szemléltetjük. A belső elemzési módszerek esetén a módszerválasztás szempontrendszerét, valamint az alkalmazható módszerek esetén az erőforrás alapú megközelítésre, kulcsfontosságú tényezők elemzésére, illetve a Porteri értéklánc elemzésre épülő belső faktor értékelő mátrix jelentőségére térünk ki. $A$ stratégiát megalapozó elemzések harmadik pillérét a versenytársak mátrix alapú értékelése jelenti. A módszerek alkalmazhatósága függ a vállalkozás formájától, múködési területétól és tevékenységének jellegétôl, amit az új gazdasági szférák (pl.: sharing) és az átalakult erőviszonyok megjelenése is bonyolít.

Kulcsszavak: stratégiai tervezés, külsó-belsô környezet elemzés, versenytárselemzés

Abstract: Increasing environmental volatility is a growing challenge for companies and businesses. The speed of economic events is changing, and the risk of uncertainty is increasing, requiring business to take a new approach to strategic planning. In the design and forming of their strategy, both the factors of the external and internal environment and the analysis of their competitors can be based on well-chosen methods. We consider the review of these methods, their application in planning and educational practice. The aim of our work, in which we present the methods that underpin the strategy applied in both domestic and international practice. The analysis of the external environment illustrates the construction and applicability of an external factor analysis matrix based on traditional PEST analysis and the Porter's five-factor model. In the case of internal factor analysis matrix, we focus on the 
approach of method choice, and on the applicable methods, the importance of the resource-based approach, the analysis of key factors and the Porter value chain analysis matrix. The third pillar of the analysis that underpins the strategy is the matrix-based assessment of competitors. The applicability of the methods depends on the form of the enterprise, the field of activity and the nature of its activities, which is complicated by the emergence of new economic spheres (e.g.: sharing) and transformed power relations.

Keywords: strategic planning, external-internal environment analysis, competitor analysis

\section{Bevezetés}

A piaci környezet az elmúlt évek során jelentősen megváltozott. A globalizáció, piaci koncentráció, a gyors információáramlás és technológiai fejlődés miatt a verseny az összes iparágban fokozódik. A korábban általánosan jellemző mennyiségi megközelítést a minőség és az ár-érték arány előtérbe helyezése váltotta fel. A gazdasági, társadalmi és természeti környezet jelentős változása már felelősebb gondolkodásra, és felelősebb döntések meghozatalára kényszeríti a vállalatokat (Fenyves - Tarnóczi, 2019). A fenti változások miatt az átfogó, stratégiai tervezés is új módszereket kíván. A stratégiai tervezés fő feladata a szervezet lehetőségeinek idejében történő felismerése és az ezekre való reagálás, stratégiai cselekvési program rendszer-személetű kidolgozása, azok kockázatainak elemzése mellett. Az eredményes stratégiaalkotás sikertényezője a megfelelő stratégiai gondolkodásmód és annak módszertani alátámasztása. Ezt szolgálja a megvalósítható és sikeres stratégiai tervkészítés. A stratégiai terv felépítésének, kimunkálásának oktatási gyakorlatunkban is alkalmazott módszertani áttekintését az 1. ábra szemlélteti. A külső környezet elemzése során a hagyományos PEST analízisre és a Porterféle öttényezős modellre épülő külső faktor értékelő mátrix (KFÉM) felépítését és alkalmazhatóságát mutatjuk be. A belső elemzési módszerek esetén a módszerválasztás szempontrendszerét, valamint az alkalmazható módszerek esetén az erőforrás alapú megközelítésre, kulcsfontosságú tényezők elemzésére, illetve a Porteri értéklánc elemzésre épülő belső faktor értékelő mátrix (BFÉM) jelentőségére térünk ki. A stratégiát megalapozó elemzések harmadik pillérét a versenytársak mátrix alapú értékelése (CPM) jelenti. Jelen cikkben a csak a külső és belső környezet elemzéséhez kapcsolódó módszerek ismertetésére térünk ki. A módszerek alkalmazhatósága függ a vállalkozás formájától, működési területétől és tevékenységének jellegétől, amit az új gazdasági szférák és átalakult erőviszonyok megjelenése is bonyolít. Ezt követően a lehetséges stratégiai irányok kiválasztása/meghatározása történhet. A stratégiai irány(ok) megválasztását követően a szervezet hosszú távú célkitűzéseit kell rögzíteni. A célkitűzések ismeretében a lehetséges stratégiai változatokat kell mérlegelni, elemezni. A tervezés utolsó láncszeme a stratégiai választás, ami abban segít dönteni, hogy mely változatot, vagy változatokat fogunk alkalmazni a megvalósítás szakaszában. Ennek újszerú a KFÉM és BFÉM elemzésekre alapozott módszere a kvantitatív stratégiai tervező mátrix (QSPM), ami stratégiaválasztást, mint döntést objektívebbé teszi. A fent említett módszerek olyan keretet adnak a stratégiai megalkotásának, mely nemcsak vállalati szinten, hanem akár ágazati, nemzeti, de egyéni szinten is alkalmazható a jövő megbízható mérlegelésére. 


\begin{tabular}{|c|c|c|c|c|c|c|c|c|}
\hline \multicolumn{9}{|c|}{ Lépés 1. Kiindulási szakasz, jövökép, küldetés } \\
\hline Mivé akar & Ink válni, ho & ová akarunk & k eljutni? & $\mathrm{Mi} \mathrm{a}$ & az alapfiloz & ófiánk (értékek & és elvárásc & \\
\hline \multicolumn{9}{|c|}{ Lépés 2. Input szakasz, feltáró analízis } \\
\hline \multicolumn{3}{|c|}{ Külsö elemzés } & \multicolumn{2}{|c|}{ Versenytárs elemzés } & \multicolumn{4}{|c|}{ Belsö elemzés } \\
\hline PEST & $\begin{array}{l}5 \text { erö } \\
\text { modell }\end{array}$ & KFÉM & \multicolumn{2}{|c|}{$\begin{array}{c}\text { CPM (versenyképességi } \\
\text { mátrix) }\end{array}$} & $\begin{array}{l}\text { Erőforrás } \\
\text { alapú }\end{array}$ & $\begin{array}{l}\text { Kulcsfontos- } \\
\text { ságú belső } \\
\text { tényezők }\end{array}$ & $\begin{array}{l}\text { Értéklánc } \\
\text { elemzés }\end{array}$ & BFÉM \\
\hline \multicolumn{3}{|c|}{ swOT } & \multicolumn{2}{|c|}{ SWOT } & \multicolumn{4}{|c|}{ SWOT } \\
\hline \multicolumn{9}{|c|}{ Lépés 3. Elemzési szakasz, potenciális stratégiai irányok } \\
\hline \multicolumn{3}{|c|}{ SPACE } & BCG & \multicolumn{2}{|c|}{ IE, GE } & \multicolumn{3}{|c|}{ GSM } \\
\hline \multicolumn{3}{|c|}{$\begin{array}{l}\text { Stratégiai pozíció és cselekési mátrix } \\
\text { (Strategic Position and Actions Matrix) }\end{array}$} & $\begin{array}{c}\text { Boston } \\
\text { Consulting } \\
\text { Group Matrix }\end{array}$ & \multicolumn{2}{|c|}{$\begin{array}{l}\text { Belsö/külsö mátrix } \\
\text { (Internal/External, } \\
\text { McKinsey, GE matrix) }\end{array}$} & \multicolumn{3}{|c|}{$\begin{array}{l}\text { Nagy stratégiai mátrix } \\
\text { (Grand Strategy Matrix) }\end{array}$} \\
\hline \multicolumn{9}{|c|}{ Lépés 4. Kijelölési szakasz, hosszú távú stratégiai célkitúzések } \\
\hline \multicolumn{2}{|c|}{ TOWS } & \multirow{2}{*}{\multicolumn{4}{|c|}{ Problémafa elemzés / célstruktúra kijelölés }} & \multirow{2}{*}{\multicolumn{3}{|c|}{\begin{tabular}{|c|} 
Generikus stratégiák \\
$\begin{array}{c}\text { Költségvezetó, differenciáló, fókusz (Low Cost, } \\
\text { Differentiation, Focus) }\end{array}$ \\
\end{tabular}}} \\
\hline \multicolumn{2}{|c|}{ TS, TW, OS, OW } & & & & & & & \\
\hline Összvállal & ti szint & \multicolumn{3}{|c|}{ Divízó szint } & \multicolumn{2}{|c|}{ Funkcionális szint } & \multicolumn{2}{|c|}{ Operatív szint } \\
\hline \multicolumn{9}{|c|}{ Lépés 5. Választási szakasz, konkrét stratégiai típusok, változatok } \\
\hline \multicolumn{3}{|c|}{ Defenzív stratégiák } & \multicolumn{3}{|c|}{ Fenntartó stratégia } & \multicolumn{3}{|c|}{ Offenzív stratégiák } \\
\hline Reorganizáció & Leválasztás & Végelszámolás & \multicolumn{3}{|c|}{ Fenntartás menedzsment } & Együttmúködési & \multicolumn{2}{|c|}{ Intenzív } \\
\hline \multicolumn{9}{|c|}{ Lépés 6. Döntési szakasz } \\
\hline & ntitatív & tratégiai te & rvező mátrix(c & Quantitative & e Strateg & Planning (QSP) & Matrix) & \\
\hline
\end{tabular}

1. ábra A stratégia terv módszertani felépítése

Forrás: Nábrádi szerk. (2019) kézirat: A stratégiai tervezés XXI. századi gyakorlata

\section{Kutatási háttér és módszertan}

A tervezés átfogó célja induláskor a vállalkozás létrehozásának előkészítése, működő vállalkozás esetén a szervezet céljai és tényleges lehetőségei közötti harmónia megkeresése és megteremtése. A tervek alapján a menedzser(ek) mérlegelhetik az ötletek megvalósíthatóságát, az ütemezést, a jövedelmezőséget, a vállalt kockázat mértékét és bizonyos esetekben a hatékonyságot. A folyamat során a controllerek segítik a menedzsereket (Fenyves, 2019). Másrészről a tervezést a jövő alakításaként lehet definiálni: a célok elérésének érdekében szükséges intézkedések, eszközök, tevékenységek következetes meghatározásaként. A stratégiai tervezés során először tisztáznunk kell a vállalkozás jövőképét és küldetését, azaz a víziót és a missziót. E két meghatározó irányvonal mentén haladva kell az üzleti tevékenység megalapozásához szükséges elemzési módszereket felmérni, és a megfelelőket kiválasztani mind a külső, mind a belső tényezők értékeléséhez. Négy fontos kérdésre próbálunk válaszolni. Nevezetesen: mit, miért és hogyan elemzünk, és mire kell külön fegyelmet szentelni az elemzés során? Mit? Csak azokat a tényezőket kell megvizsgálni, amelyek befolyásolhatják a vállalkozás fő célját (az összes többi tényező vizsgálata nem szükséges). Miért? A külső környezet vizsgálata alapján megpróbáljuk feltárni a várható jövőbeli változásokat a múlt és a jelen eseményeinek megértése alapján. Hogyan? Csak azokat a tényezőket tekintjük át, amelyek lehetőséget biztosítanak a vízió megvalósítására, vagy veszélyt jelenthetnek az elérésénél. Ehhez léteznek nemzetközileg elismert analitikai módszerek, amelyek felhasználhatók potenciális alternatíváink meghatározására. Mire kell külön figyelni? Arra, hogy külső tényezőket a vállalat nem befolyásolhatja, nincs rá közvetlen hatása, míg a belső tényezők saját hatáskörében változtathatók, módosíthatók. A jövőközpontú stratégiai 
tervezésben alapvető fontosságú ennek a két területnek a körültekintő vizsgálata a mai gyorsan változó gazdasági környezetben új gyakorlati szempontú módszerekre alapozva.

A stratégia kulcskérdése az, hogy miként lehet megmagyarázni, hogy a hasonló erőforrásokkal rendelkező vállalkozások teljesítménye és jövedelmezősége eltérő (Rumelt-Scendel-Teece, 1991). Ennek egyik oka, hogy a 21. század egyik fontos kihívására, miszerint alkalmazkodniuk kell a globalizációhoz és a hozzá kapcsolódó gyorsan változó technológiákhoz, a fogyasztók és más érdekeltek igényeihez, ám erre a vállalkozások eltérően reagálnak. A stratégia alkotás célja, hogy a társaság versenykörnyezetben jól pozícionálja magát, jobban megfeleljen ügyfelei igényeinek, mint versenytársai. Egy hatékony, jól megválasztott, jövőközpontú stratégia ötvözi a külső lehetőségeket és a belső erőforrásokat (Bittner et al., 2018). A külső környezeti tényezők folyamatos mozgásban vannak, új lehetőségeket és új veszélyeket teremtve a vállalat számára. A bizonytalanságok, a fenyegetések és a korlátok miatt az üzleti vállalkozások nagy nyomás alatt vannak, és megpróbálják megtalálni az egészséges túlélés módját és eszközeit. Ilyen körülmények között a jó lehetőség a stratégiai menedzsment eszközrendszerének lehető legjobb kihasználása, amely segítheti a vállalati vezetést a lehetőségek feltárásában, és ezzel egyidejűleg a fenyegetések minimalizálásával az optimális és sikeres működés elérésében. A külső környezet és az iparág kihívásainak megfelelni képes üzleti vállalkozásokat a piac elismeri és ők valóban sikeresek lehetnek (Wright et al. 1995). Feurer és Chaharbaghi (1995), valamint Feurer és Chaharbaghi (1997) szerint az üzleti lehetőségeket a stratégiai tervezés során lehet célokká formálni. Az Ansoff (1957) által kidolgozott módszertan megmutatta a stratégiai tervezés hasznosságát. Az 1980-as években a stratégiai tervezés fókusza áthelyeződött, és elindult a koncepciók és technikák széles skálájának kidolgozása a jövőtervezés terén, amelynek célja az üzleti lehetőségek feltárása és kiaknázása. A kisvállalkozásokban a stratégiai tervezést a külső környezet körültekintő elemzésével, megértésével kell megalapozni, mivel minden vállalkozásnak dinamikusan változó környezete van (Spillan, Ziemnowicz, 2003). A külső környezeti elemzése elősegíti a tervezés hatékonyságának és eredményességének növelését a kisebb vállalkozásokban is (Kraus, Harms, Schwarz, 2006). Hodgetts és Kuratko (2001) megemlítették, hogy releváns információk előállítása és a környezet változásainak megértése révén a stratégiai tervezés hozzájárulhat a teljesítmény növeléséhez. A változó külső környezeti feltételek befolyásolják valamennyi vállalat stratégiai irányát és általános teljesítményét (O’Regan et al., 2008). A vállalkozások hosszú távú lehetőségei általában annak külső környezetében generálódnak (David, 2019; Hitt et al., 2011). A vállalatok tervezési gyakorlatuk révén tudnak felkészülni a változások kezelésére, mivel dinamikusan változó környezettel kell szembenézniük (Phelps, Chan, Kapsalis, 2001, Khan, Khalique, 2014). A külső környezet elemzése az olyan tendenciák és események azonosítására összpontosít, amelyek kívül esnek egyetlen vállalat hatáskörén, például a növekvő külföldi verseny, a népesség változása, a társadalom elöregedése, vagy a közösségi média forradalma. Egy külső környezeti elemzés feltárja a szervezetet érintő legfontosabb lehetőségeket és veszélyeket, és útmutatást ad a vezetőknek a stratégiák megfogalmazásában, a kockázatok elkerülésében és a lehetőségek kihasználásában (David, et al., 2019).

„Ha ismered az ellenséget és ismered magad, akkor nem kell félned száz csata kimenetelétől...” idézhetjük Sun Tzu, BC 4. századi hadvezértől. Amint azt számos szerző demonstrálja, a stratégiai gondolkodás irodalmának hosszú történelme van, mivel a belső és a külső tényezők alapvető ismerete, meghatározza a szervezet legfóbb és hosszú távú stratégiáját. A stratégiai tervezés módszertanának különösen fontos része a szervezet belső elemzésére használható technikák áttekintése. Jelen részben a 
belső elemzés, vagy más néven belső audit elemzési módszereinek áttekintése történik többnyire az amerikai stratégiai menedzsment stratégiai tervezési gyakorlata alapján, amelyet Fred R. David művei révén ismerhetünk meg. Ezeket a módszereket saját oktatási gyakorlatunkban adaptáltuk az európai sajátosságokhoz igazított stratégiai tervezési gyakorlat során. A stratégiai elmélet történetét és a stratégiai tervezés fejlesztését számos magyar és nemzetközi irodalom tárgyalja (Csath, 1990, 2004; Whittington, 2001; Fülöp, 2008; Gulyás, 2014; Balaton-Tari, 2014). Magyarországon a vállalati stratégiai elmélet fejlesztésének szakaszait a Balaton Károly és Tari Ernő társszerzők, valamint Fülöp Gyula 2014ben kiadott, „Stratégiai menedzsment” című könyve, és Nábrádi, A.-Pupos, T. 2014-ben kiadott „Stratégiai és üzleti tervezés” című műve alapján mutatjuk be. Ezen művek alapján négy időszakot lehet megkülönböztetni a vállalati stratégia fejlődéstörténetében. Ezek a szakaszok a következők: A vállalati tervezés tapasztalatai, (kb. 1965-ig); a stratégia modern elméletének kezdete (körülbelül 1965-1970); a stratégiai tervezési modellek és módszerek fejlesztése, a stratégiai tervezés korlátozásai (kb. 19701980); valamint a stratégiai menedzsment elméletének fejlesztése (körülbelül 1980-tól az ezredfordulóig) (Balaton - Tari, 2014). A belső elemzés módszertanának ma is alkalmazott technikái nagynevű szerzőktől származnak. A „versenyképes stratégia” és az értéklánc módszere Porter (1985) nevéhez kötődik. A modell lényege az értékteremtő tevékenységek stratégiai szempontból releváns szakaszokra bontása, amelyek elválaszthatók egymástól az értéklánc erős és gyenge összeköttetéseinek azonosítása érdekében (Fülöp, 2008). A modell alkalmasnak bizonyult az elsődleges és a kiegészítő tevékenységek szétválasztására a vállalaton belül. A korábban alkalmazott analitikai módszerek az egyes tevékenységeket grafikusan ábrázolják. Az erőforrás-alapú elemzés során a stratégia kidolgozásának folyamata nem a versenykörnyezet igényein alapult, hanem a szervezet rendelkezésére álló erőforrások szintjén (Balaton - Tari, 2014). Az erőforrás-alapú megközelítés teoretikusai között szerepelt Barney, akinek koherens elméletként kidolgozott megközelítése szerint az erőforrás nem más, mint a társaság tárgyi és immateriális erőforrásainak összessége. Manapság az erőforrásokat közgazdaságilag szélesebben értelmezzük: a föld, a tőke, az emberi erőforrások, a vállalkozó személye és kapcsolatrendszere, valamint az információ területére kiterjesztve. Az erőforrásokra alapozva, és azokat a vállalkozás specialitásai szerint bővítve, vagy szűkítve kulcsfontosságú tényezők azonosítása és értékelése alapján is végezhetünk belső elemzést.

A stratégiai tervezés során és annak részeként a stratégiai tervezésben a vízió és a misszió megfogalmazása után elsőként a külső környezet elemzés folyamatára koncentrálunk, amely egy szervezet elemzésének első makro-, és mikro-szintű vizsgálata. A külső elemzés fô célja a kihasználható lehetőségek és elkerülhető, vagy enyhítendő veszélyek azonosítása. Nem célunk az összes lehetséges tényező felsorolása, mivel az összes tényező száma végtelen lehet. A külső környezet fejleményeinek azonosításának és elemzésének egyik módja a tényezők prioritási mátrixának használata. A külső tényezők alacsony, közepes, vagy nagy hatással lehetnek a vállalatra, és bár egyes esetekben a bekövetkezés valószínűsége alacsony, a külső tényezők ismerete és hatásuk kimenetelének becslése elengedhetetlen a jövőbeni stratégia kialakítása során. A vállalat külső környezeti tényezői azok a kulcsfontosságú gazdasági, társadalmi, környezeti és technológiai tényezők és trendek, amelyek megítélése során figyelembe kell vennünk, hogy hosszabb távon milyen hatást gyakorolnak a vállalatra. A tényezők prioritási mátrixa felhasználható a vezetők számára annak eldöntésére, hogy mely tendenciákat kell csupán átvizsgálni (alacsony prioritású), és melyeket kell stratégiai tényezőként figyelemmel kísérni (kiemelt prioritás). Cikkünkben bemutatjuk a külső és belső környezeti tényezők 
elemzésének legfontosabb módszereit, a közismert elemzési módszereket követve, mint például a STEP elemzés, a Porter 5 erők modellje és az újabban alkalmazott külső faktor értékelő mátrixot (KFÉM). A belső elemzési módszerek esetén az erőforrás alapú megközelítésre, kulcsfontosságú tényezők elemzésére, illetve a Porteri (1985) értéklánc elemzésre épülő belső faktor értékelő mátrix (BFÉM) jelentőségére térünk ki. A fent ismertetett módszerek olyan alapot adnak a stratégiai megalkotásának, mely nemcsak vállalati szinten, hanem akár ágazati, nemzeti, de egyéni szinten is alkalmazható a jövő megbízható mérlegelésére. A módszerek a stratégiai menedzsment irányadó forrásaként tekintett legutóbb 17. kiadását, 2019-ben közzétett Fred R. David et al., könyve alapján ismertetjük, melynek címe Concepts and Cases, Strategic Management, A Competitive Advantage Approach.

\section{Eredmények}

\subsection{Külső környezet elemzési módszerek}

A külső, makro és mikro környezeti tényezőket öt nagy kategóriába lehet sorolni:

- gazdasági tényezők,

- társadalmi, kulturális, demográfiai és környezeti tényezők,

- politikai, kormányzati és jogi tényezők,

- technológiai, technikai tényezők

- az iparági verseny tényezői

Az információk, melyek alapján a tényezők hatását megítélhetjük, forrásaikat tekintve eltérőek lehetnek. Használhatunk úgynevezett közzétett (jelentések, folyóiratok) és nem közzétett (vásárlói felmérések, találkozók, piackutatás, beszélgetések) forrásokat. Számos kiváló internetes és közösségi hálón elérhető forrás található a stratégiai információk gyűjtésére, például a finance.yahoo.com, a hoovers.com, a globaledge.msu.edu és a vállalati web helyek.

A külső tényezők azonosítása és rangsorolása során figyelembe kell vennünk azok hitelességét és, hogy azok megfelelnek a következő a kritériumnak: következetesség, mennyiségi mérhetőség, összehasonlíthatóság, osztályozhatóság. Fontos, hogy a vizsgált tényezők szorosan kapcsolódjanak a küldetést teljesítő, vagy a küldetést akadályozó tényezőkhöz. A külső tényezők befolyásolják a kínált, vagy kifejlesztett termékek és szolgáltatások típusát, a piaci pozicionálási stratégiákat, valamint a vállalat tevékenységét és jövőjét.

\section{STEP-elemzés}

A STEP elemzés során a társadalmi, technológiai, gazdasági és politikai tényezőket, azok várható hatásait vizsgáljuk a vállalkozás jövőbeni céljaira való tekintettel. Társadalmi tényezők azok, amelyek az emberek életmódját, munkáját, fogyasztását, egészségi állapotát, a szabadidejük eltöltését alakítják. A vásárlók ízlése és fogyasztási trendjei folyamatosan változnak, ami közvetlen hatással van a vállalkozások termékfejlesztésére, a kínált szolgáltatások körére, az árakra, a fogyasztókért folytatott versenyre, ezért nagyon fontos, hogy ismerjük és vizsgáljuk őket. Példaként elemezhető kategóriák: a népességváltozás, a születések, a halálozások, a házasságok, a válások száma, a bevándorlás és 
emigráció, a jövedelmek alakulása, a vallások és felekezetek helyzete, a szokások, a társadalmi felelősségvállalás kérdései, az oktatás, az életmód, a szolgálatokhoz való hozzáállás, az egészségügy helyzete, az etnikumok megoszlása stb.. Technológiai tényezők közül kiemelhető a beruházások helyzete, típusa, az innovatív iparágak és fejlesztések, a vállalkozások informatikai aktivitása, az alkalmazott mobil technológiák és alkalmazások köre, a robotika, illetve a mesterséges intelligencia jelenléte, amelyek szintén befolyásolják a munkaerő és a termelés helyzetét. Manapság egyetlen vállalkozás, vagy iparág sem létezhet a feltörekvő technológiai fejlesztések alkalmazása nélkül. A csúcstechnológiával rendelkező iparágakban a legfontosabb technológiai lehetőségek és veszélyek azonosítása lehet a külső elemzés legfontosabb része (David et al., 2019). Alapvető fontosságú az infrastruktúra helyzetének, az elérhető szolgáltatások és hálózatok elemzése, a $\mathrm{K}+\mathrm{F}$ és innováció szintjének vizsgálat. A gazdasági tényezők közvetlen hatással vannak az egyes vállalkozási stratégiák potenciális vonzerejére. A kedvező gazdasági feltételek sok szervezet számára előnyösek, mivel a gazdasági növekedés általában csökkenti a munkanélküliséget, növeli a vásárlói bizalmat, a fogyasztást és növeli a jövedelmet. Ennek kapcsán vizsgálható kategóriák: a rendelkezésre álló jövedelem és a hitelezés szintje, az emberek vásárlási hajlandósága, a kamatlábak alakulása, az inflációs ráta, pénzpiaci folyamatok alakulása, a GDP trendje, a munkanélküliségi ráta és trendje, az import/export aránya és iránya, az áringadozások, a monetáris és fiskális politika, az adók mértéke és típusai, a támogatások típusa, mértéke, stb.. A politikai tényezők között fontosabbak: a helyi és a külföldi kormányok intézkedései, a legfontosabb szabályozók, a támogatók, a civil szervezetek, a munkaadók és egyéb érdekvédelmi szervezetek múködése. A politikai, kormányzati és jogi tényezők szintén kulcsfontosságú lehetőségeket, vagy fenyegetéseket jelentenek mind a kis, mind a nagy vállalkozások számára. Az irodalmi források mindazonáltal egyetértenek abban, hogy a külső tényezőként azok azonosíthatók, amelyekre a gyakorlatban egyetlen cég sem lehet közvetlen hatással, viszont valamennyi gazdasági és társadalmi egység működését befolyásolják. Sajátos eseteket is találhatunk ezzel szemben, ha például megvizsgáljuk Debrecen város helyzetét, megállapíthatjuk, hogy az elmúlt 3-4 évben 14 új befektető (BMW, Krones, Continental, Thyssenkrupp, Diehl Aviation stb.) jelent meg, és több másik (NI, Scheffler, Richter, stb.) hajtott végre fejlesztést, vagy újbóli befektetés a városban. Mi a siker titka? Ezekért a vállalatokért a régió országai és nagyobb városai (azaz a külső környezet) versenyeznek, így a külső tényezők (politikai, gazdasági, társadalmi vagy technológiai) a versenyben maradás és a befektetések bevonzása miatt alakíthatóvá válnak az új célok és igények függvényében. Debrecen esetében is találunk olyan tényezőt, amelyet a város külső, kedvező tényezőként kínálhat a befektetőnek. (Például politikai téren: állami támogatás, gazdasági tényezőként helyi adózási kedvezményt nyújthat, vagy adómentességet kínálhat; társadalmi tényezőként speciális befektetői igényeket vehet figyelembe az oktatás, vagy az egészségügy fejlesztése terén. Például a Debreceni Egyetem speciális szakokon hallgatókat képezhet a befektetők számára, pl.: pilóták, mérnökök. Technológiai tényezőként infrastruktúrát bővíthet, vagy építhet ki, nemzetközi iskolát hozhat létre.) A fenti példa jelzi, hogy egy meghatározó vállalkozói érdekek esetén, amely jelentős hatással lehet a régió fejlődésére, a külső tényezők megváltoztathatók.

Porter öt erő modellje: A Porter (2006) öt erőből álló versenyvizsgálati modellje sok iparágban, széles körben alkalmazott módszer a stratégiák kidolgozásához. A vállalkozások közötti verseny intenzitása a különböző iparágakban nagyon eltérő lehet. Michael Porter átirányította a figyelmet arról, hogy csak néhány versengő céget vizsgáljunk az iparági verseny elemzése során. Egy szélesebb elemzés felé terelte a vállalkozásokat, amely magában foglalja a teljes iparágat, mint versenyszférát, valamint a jelenlegi és 
várható, új versenytársakat, a beszállítókat, a vásárlókat és a helyettesítő termékeket is. Porter szerint az adott iparág versenyhelyzete, jellege öt erő összetételének, hatásának tekinthető, melyek a következők:

1. A verseny erőssége az iparági szereplők, azaz versengő cégek között

2. Új versenytársak lehetséges belépése, fenyegetése

3. A helyettesítő termékek lehetséges fejlesztése

4. A beszállítók alku ereje, pozíciója

5. A vevők és fogyasztók alkupozíciója

Porter, (2006) öt erő modelljének alkalmazása három lépésben foglalható össze, melynek eredményeképp megállapítható, hogy az adott iparágban a versenypozíció olyan-e, hogy a vállalat elfogadható profitot tudjon elérni. Elsőként meg kell határozni minden egyes tényező erősségének kulcsfontosságú aspektusait vagy elemeit, amelyek befolyásolják annak alakulását, azaz jellemezzük az egyes erőket. Második lépésként értékelni kell, mennyire erősen befolyásolják az egyes elemek a cég helyzetét, mennyire fontosak azok a számára. Végül el kell dönteni, hogy, az elemek együttes ereje alapján megéri-e a vállalkozásnak az iparágban maradni, vagy inkább be kell lépni egy újba. A modell értékelésében olyan módosító tényezők is lehetnek, mint a változó gazdasági környezet, a globalizáció és az információs technológiák, valamint a vásárlói viselkedés alakulása. Módosult elemzési struktúrát követel meg az új gazdasági szféraként megjelent „sharing”, melybe a világ jelenleg legnagyobb vállalatait találhatjuk, olyan vállalatokat, mint pl. AIRBNB, UBER. Ezen cégek esetében a beszállítói és az ügyfélkapcsolatok nem hagyományos módon működnek, erőforrásaik más jellegűek, mint a klasszikus közgazdaságtanban ismertek, tehát finomítani kell az elemzési módszereket. És egyes iparágak esetében a helyettesítő termékek kategóriája nem értelmezhető, mert túl sok a helyettesítési lehetőség, vagy éppen abszolút korlátozott, mint például az orvosi eszközök és alapanyagok esetén, vagy az építőiparban.

\section{Külső faktor/tényező értékelő mátrix}

A külső faktor értékelő mátrix (KFÉM) lehetővé teszi a stratégák számára, hogy összefoglalják és számszerúsítve kiértékeljék a gazdasági, társadalmi, kulturális, demográfiai, környezeti, politikai, kormányzati, jogi, technológiai és az iparági versenyre vonatkozó információkat. A KFÉM öt lépésben alakítható ki:

1. Gyűjtsünk össze 10 és 20 azonosított tényezőt/faktort, mind a lehetőségek, mind a veszélyek közül, amelyek befolyásolják a vállalkozás és az iparág jövőbeni működését.

2. Minden tényezőhöz rendeljünk súlyt 0 (nem fontos) és 1 (rendkívül fontos) közötti értékkel. A súly azt jelzi, hogy ennek a tényezőnek milyen relatív jelentősége van a cég sikere szempontjából az iparában. A súly kiszámításához használhatjuk Guilford páros összehasonlítás módszerét. A súlyok összege 1,00 értéket adjon.

3. Mindegyik külső azonosított és besorolt faktorhoz rendeljünk 1 és 4 közötti egész értéket (rangszámot), jelezve, hogy a cég jelenlegi stratégiája milyen mértékben reagál az adott tényezőre: ahol 4 jobb, 3 átlag feletti, 2 átlagos és 1 gyenge reakciót jelent. 
4. Szorozzuk meg az egyes tényezők súlyát az osztályozással a súlyozott pontszám meghatározásához.

5. Adjuk össze a súlyozott pontszámot faktoronként a súlyozott pontszám meghatározásához.

Az átlagos súlyozott pontszám 2,5. A teljes súlyozott pontszám 4.0 azt jelzi, hogy egy szervezet kiemelkedő módon reagál az iparágban meglévő lehetőségekre és veszélyekre. Más szóval, a cég stratégiája hatékonyan kihasználja a meglévő lehetőségeket és minimalizálják a külső fenyegetések lehetséges káros hatásait. Ha a teljes pontszám 1,0-hez közelít, az azt jelzi, hogy a cég jelenlegi stratégiában nem használják ki megfelelően a lehetőségeket, vagy nem tudják hatékonyan elkerülni a külső fenyegetéseket.

A stratégiai menedzsment folyamatában és annak részeként, a stratégiai tervezés második elemzési szintjén a belső elemzés folyamatára koncentrálunk. A belső elemzési folyamat fő célja az erősségek és gyengeségek feltárása és értékelése a szervezet minden területén. A kidolgozás folyamatába a döntéshozásban érintett menedzsereket, a szervezet vezetőit és a munkavállalókat is be kell vonni a cég erősségeinek és gyengeségeinek pontos meghatározása érdekében. A belső elemzés, amelyet egyfajta auditnak is nevezhetünk, megköveteli a hiteles információgyüjtést és asszimilálást a cég vezetésével, marketing, pénzügyi, számviteli, termelési, múködési, $\mathrm{K}+\mathrm{F}$, valamint a menedzsment információs rendszerével, múködésével, a vállalkozás kultúrájával kapcsolatban. Be kell vonni az értékelésbe az imázs és a hírnév kapcsán értékelhető tényezőket is. A belső környezet elemzését a külső környezet elemzésével párhuzamosan, de más érintettek bevonásával kell végezni. A szakirodalomban számos eljárás létezik a belső elemzésre elvégzésére. Ilyenek például: az erőforrás alapú értékelés (RBV), a kulcsfontosságú belső tényezők (KIF) elemzése, értéklánc-elemzés (VCA), a tevékenységalapú költségszámítás, ABC-elemzés, belső faktor értékelő mátrix (BFÉM) (Bittner et al., 2018). Cikkünk jelen részében az erőforrás alapú megközelítést, a kulcsfontosságú tényezők vizsgálatát és a belső faktor értékelő mátrixot tárgyaljuk.

A vállalkozás belső elemzésekor figyelembe kell venni annak képességeit, és arra összpontosítunk, hogy a vállalat miként képes megfelelni az érdekeltek elvárásainak. A belső elemzés ezen a ponton kapcsolódik a fent említett küldetéséhez és a szervezet jövőképéhez. A stratégiai tervezés során először tisztáznunk kell a belső elemzés általános alapjait, amely a belső tényezők azonosítását jelenti a megfelelő módszerek felhasználásával. Mindig a társaság belső erősségeire és gyengeségeire összpontosítunk. Ezeket az elemeket a cég befolyásolhatja, vagy módosíthatja a hatékonyabb múködés érdekében.

Az erőforrás-alapú megközelítés azt jelenti, hogy egymás után vizsgáljuk a legfontosabb erőforrás- és tőkekategóriákat, majd értékeljük azokat a jövőképben felvázolt fő célkitűzés elérése szempontjából. Mik ezek az erőforrások? Az erőforrások főbb csoportjait értékelhetjük a következő csoportosításban: fizikai és technológiai erőforrások, pénzügyi erőforrások; emberi erőforrások; szervezeti erőforrások, kultúra; márka, valamint hírnév, az üzleti vagy cégérték. Az RBV elmélete szerint az erőforrások valójában azok, amelyek segítenek a vállalkozásoknak az erősségei kiaknázásában és a gyengeségei semlegesítésében. Elsőként célszerű az állóeszközöket értékelni, beleértve az immateriális javakat, a tárgyi eszközöket és a pénzügyi eszközöket, majd a forgóeszközök kategóriáit. Az elemzés során áttekintjük az eszközök belső összetételét és volumenét, megvizsgáljuk, hogy, jelenlegi állományuk, értékük függvényében mennyire vagyunk képesek megfelelni a jövőképnek. Az eszközöket követően 
megvizsgáljuk az emberi erőforrásokat. Elemezzük, mennyiségi és mennyiségi szempontból az alkalmazottainkat: diplomások, férfiak és nők arányát, az állandó és időszakosan alkalmazottak állományát, költségét, a szakmai tapasztalat, a személyes készségek és képességek adta előnyöket, a fluktuáció mértékét, a munkahelyi légkört, a vállalat szervezetét, a vállalati kultúrát és ösztönző rendszert. Felmérjük, hogy van-e személyi fejlesztési program az alkalmazottak számára, tisztában vannak-e a vállalat küldetésével és jövőképével? A szervezet kultúrája mennyire fontos az alkalmazottak számára?

Ha értékeljük egy szervezet, vagy egy vállalkozás belső tényezőit, akkor alkalmazhatjuk az úgynevezett kulcsfontosságú belső tényezők elemzésének módszerét is (KIF). Egy szervezet esetében a vizsgálatot ki kell terjeszteni a következő tényezőkre: menedzsment, marketing, pénzügy-számvitel, termelés és szolgáltatás, kutatás és fejlesztés, valamint a menedzsment információs rendszer (MIS) (Bittner et al., 2018). A kulcsfontosságú belső tényezők csoportosítása ebben az értelemben nem véletlenszerű. Az üzleti stratégiai szempontjából az elemzés legfontosabb eleme maga a menedzsment. Tudomásunk szerint egyetlen vállalkozás sem lehet sikeres pusztán azért, mert kiváló terméket készítet vagy, mert nem adósodott el. Ezért célszerű meghatározni, hogy a vezetés mely területei felelnek az elérendő célért. A menedzsmentnek öt jól meghatározható területe van. Ezek a tervezés, szervezés, motiváció, csapatépítés és ellenőrzés, melyek előre összeállított az egyes területekre vonatkozó kérdéseket tartalmazó sablonok alapján is elemezhetők. A kulcsfontosságú tényezők között a vállalat marketing területének értékelése nem könnyű feladat, mivel a marketing mix minden elemét át kel tekinteni, mint például vevőelemzés, piaci szegmentálás, értékesítési trendek termékek és szolgáltatások jellemzői, termék- és szolgáltatástervezés, árképzési gyakorlat, disztribúció, disztribúciós csatornák értékelése, marketingkutatás gyakorlata, piackutatás, reklám promóció. A pénzügyi számviteli helyzet elemzésének alapját társaság belső dokumentációja, éves beszámolói, a mérleg és az eredménykimutatás jelenti. A pénzügyi és számviteli mutatókat elsősorban a jelenre vonatkozóan kalkuláljuk, de fontos ezek idősoros elemzése is, mivel a mutatók alakulásnak okai, a levonható következtetések és várható következmények ennek segítségével tárhatók fel. A pénzügyi-számviteli adatok elemzését öt fő csoportban vizsgáljuk a stratégiai tervezési szakirodalma alapján (Bittner et al., 2018): fizetőképesség, eladósodottság, pénzügyi aktivitás, jövedelmezőség és növekedés. Mindegyik esetben numerikus mutatók elemzését végezzük el a vállalat pénzügyi helyzetének megítélése céljából. Bár ezek a mutatók iparág-specifikusak, az elsődleges (bányászat, mezőgazdaság), a másodlagos (feldolgozás, gépgyártás) és a harmadlagos (szolgáltató, kereskedelem) ágazatokban eltérően értelmezhetők, a mutatók többsége ágazat-semleges. A termelés és a szolgáltatás értékelése az összes olyan tevékenység elemzéséből áll, amely az inputokhoz kapcsolódó kiadásokat, az árutermelést, a szolgáltatásokat és a bevételek realizálását és a készletgazdálkodást is érinti. A terület elemzésének fő elemei a következők: termelési és/vagy szolgáltatási folyamat, kapacitások és kapacitáskihasználás, készlet- és készletgazdálkodás, munkaerőfelhasználás, minőség és minőségbiztosítás. A belső kulcsfontosságú tényezők következő eleme a K + F+ I, ugyan nem meghatározó szempont a tömegtermékeket előállító primer szektor számára, annak azonban olyan iparágak, ahol az innovációs eredmények és fejlesztések a stratégiai meghatározó elemei. Ezek alkalmazása történhet egyedileg cégenként, vagy klaszterekben. A menedzsment információs rendszer (MIS) a vizsgálat utolsó eleme. A cégek többségénél általában olyan számítógépes rendszerre utal, amely lehetővé teszi a vezetők számára, hogy kezeljék, kiértékeljék és hatékonyan felhasználják a szervezeti egységeket érintő információkat. A vezetői információs rendszer az adatmennyiség és 
komplexitás miatt nélkülözhetetlen eleme a vállalkozások hatékony működtetésének. Amellett, hogy a vezetői döntéseket segíti, tájékoztathatja a munkavállalókat és az érdekcsoportokat is a vállalkozás működésértől.

Az értéklánc elemzése nem új módszer a belső tényezők elemzésénél, de a megfelelő információk birtokában az egyik leghatékonyabb módszer a komparatív előnyök, a hozzáadott érték és a költséghatékonyság feltárásában, és azok versenytársakkal való összevetésében. Alapvetően egy speciális megközelítéssel elemzi a költségeket. A módszer valóban hatékony, ha a vállalat termelése a teljes termékláncot lefedi, de akkor is jól használható, ha az ellátási lánc szűkebb szegmenseire korlátozódik. A módszerben Porter később a termelés mellett a szolgáltatási folyamatokra is kidolgozta az elemzés módszerét.

A belső elemzést összegző és objektíven értékelő módszer a belső faktor értékelő mátrix (BFÉM), melyben rendszerezzük és számszerűsítjük az előző módszerek segítségével azonosított erősségeket és gyengeségeket. Alkalmazásával alapvetően két kérdésre keresünk választ: hol van szükség megerősítésre (gyengeségek) és milyen területek segítik a cél elérését (erősségek), a küldetés megvalósítását. Kivitelezése a KFÉM-mel azonos módon 5 lépésben történik. A faktorok rendszerezése erősségek és gyengeségek alapján, majd a súlyok és rangszámok kialakítása, szorzása és összegzése történik meg. Az átlagos súlyozott pontszám 2,5. A maximális pontszám 4.0 azt jelzi, és ha a kapott eredmény hozzá közelit az azt jelenti, hogy egy szervezet képes erősségei révén kompenzálni a gyengeségeit, a célok elérését támogatni. Ha a teljes pontszám 1,0-hez közelít, az azt jelzi, hogy a cég jelenleg túl sok gyengeséggel rendelkezik belső tényezőit tekintve, ezért a célok elérését ez korlátozhatja, vagy meg is akadályozhatja.

A cikkben tárgyalt külső és belső környezet elemzési módszerek közül a KFÉ és BFÉ mátrixok alkalmazása új eleme lehet a stratégiai terveket magalapozó elemzéseknek, melyek a terv teljes kimunkálása során a több elemzési metódusban is alkalmazásra kerülnek. A stratégiai irányok meghatározásánál is szerepelnek az külső -belső tényezők összesített mátrixában, valamint a választható stratégiák értékelésénél, kvantitatív stratégiai tervező mátrix (QSPM) alapját is ez a két mátrix adja. A végső döntés, azaz a megvalósítandó stratégia tehát a külső és első környezet megalapozott és hiteles adatok felhasználásával elkészített elemzési módszereitől, és azok vízióval és misszióval összhangjától függnek, ami a stratégiai terv sikerének záloga.

\section{Következtetések}

A világpiacon és az iparágakban tapasztalható növekvő bizonytalanság azt jelenti, hogy a külső elemzés a stratégiai menedzsment folyamat kifejezett és létfontosságú részévé vált. A stratéga alkotás egyik legfontosabb feladata egy hatékony külső és belső elemzési rendszer fejlesztésének biztosítása. Ez magában foglalja az információs technológia használatát egy múködőképes, versenyképes elemzési rendszer kidolgozására. A STEP elemzés, a Porter öt erő modellje és az KFÉM segíthet a környezet, a piac és az iparág értékelésében, ám ezeket az eszközöket jó intuícióval kell kiegészíteni a döntéshozók részéről. A külső lehetőségek felismerése önmagában nem garantálja a sikert, ha nem állnak rendelkezésre megfelelő források, és fordítva. A stratégiai tervezés oktatási gyakorlata során azt tapasztaltuk, hogy a hallgatók valóban élvezik ezt a témát. A tárgy nagy előnye számukra, hogy 
elsajátítva a stratégiai tervezés gyakorlatát, a későbbiekben vezetőként, vagy alkalmazottként jobban teljesíthetnek, ha megértik, hogy tervező munkájuk hogyan befolyásolja a cég más területeit és tevékenységeit. Amikor a gyakorlatban a belső elemzés során a marketing- és gyártási vezetők, vagy a kapcsolódó divíziókban dolgozó alkalmazottak megvitatják a belső erősségekkel és gyengeségekkel kapcsolatos kérdéseket, jobban megismerik az összes funkcionális területet, azok problémáit, feladatait és igényeit. Azokban a szervezetekben, amelyek nem használnak a stratégiai menedzsment részeként a stratégiai tervezést, ott a marketing, pénzügyi és gyártási vezetők gyakran nem lépnek ilyen szinten kapcsolatba egymással. A külső elemzéssel összehasonlítva a belső elemzés folyamata több lehetőséget biztosít a résztvevők számára annak megértéséhez, hogy a munkafolyamatok, a részlegek hogyan illeszkednek egymáshoz és az egész szervezethez. (F. R. David et al., 2019) A belső elemzés elvégzése tehát kiváló eszköz, vagy fórum a kommunikációs folyamatok javítására is a szervezeten belül.

\section{Hivatkozások}

[1] Ansoff, I.: Strategies for Diversification, Harvard Business Review, Vol.35 Issue 5,Sep-Oct 1957,pp.113-124

[2] Bittner B.-Madai H.-Nagy A.-Nábrádi A. (2018): In Szerk: Nábrádi: A stratégiai tervezés gyakorlata. Debreceni Egyetem, Debrecen, pp. 7-158. ISBN 978-963-490-053-5

[3] Csath M. (1990): Stratégiai vezetés-vállalkozás. Közgazdasági és Jogi Könyvkiadó, Budapest, pp. 9-205. ISBN 963-222-218-0

[4] Csath M. (2004): Stratégiai tervezés és vezetés a 21.században. Nemzeti Tankönyvkiadó, Budapest, pp. 12-36. ISBN 963-19-5251-7

[5] David, F. R.-David, F. R. David M. (2019): STRATEGIC MANAGEMENT: A Competitive Advantage Approach, Concepts and Cases, 17th Edition. Pearson Education, pp. 32-276. ISBN 978-1-29214849-6

[6] Fenyves V. (2019): Controllerekel szembeni munkaerőpiaci elvárások vizsgálata CONTROLLER INFO VII : 4 pp. 33-40. , 8 p.

[7] Fenyves V. - Tarnóczi T. (2019): Examination of the expectations of controllers on the labour market

[8] CORPORATE OWNERSHIP AND CONTROL 17 : 1 pp. 60-70. , 11 p.

[9] Feurer, R., - Chaharbaghi, K. (1995). Strategy development: past, present and future. The dynamic environments of today require a more dynamic approach to strategy development. Management Decision, 33(6), 11-21.http://dx.doi.org/10.1108/00251749510087614

[10] Fülöp Gy. (2008): Stratégiai Menedzsment: Elmélet és gyakorlat. Perfekt Kiadó, Budapest, pp. 1156. ISBN 978-963-394-748-7

[11] Hitt, M.A., Ireland, R. D., Sirmon, D. G., \& Trahms, C. A. (2011). Strategic entrepreneurship: creating value for individuals, organizations, and society. Mays Business School Research Paper No.2012-19 
[12] Hodgetts, R. M., - Kuratko, D. F. (2001): Effective Small Business Management. Dryden, Fort Worth, TX

[13] Gulyás L. (2014): Stratégiai Menedzsment: Szun-Ce-tól a „Kék Óceánig”. JATEPress, Szeged, pp. 1927. ISBN 978-963-315-204-1

[14] Khan, M. - Khalique, M.W.J (2014): Strategic Planning and Reality of External Environment of Organizations in Contemporary Business Environments https://www.researchgate.net/publication/271712548_Strategic_Planning_and_Reality_of_Exte rnal_Environment_of_Organizations_in_Contemporary_Business_Environments

[15] Kraus, S., Harms, R. \& Schwarz, E. J. (2006). Strategic planning in smaller enterprises-new empirical findings. Management Research News, 29(6), 334344.http://dx.doi.org/10.1108/0140917061068385

[16] Marosán Gy. (2002): Stratégiai menedzsment. Múszaki Könyvkiadó, Budapest. pp. 44-118. ISBN 963-16-3045-5

[17] Marosán Gy. (2006): A 21. század stratégiai menedzsmentje. Múszaki Könyvkiadó, Budapest. pp. 130-139. ISBN 963-16-6008-7

[18] Nábrádi A. (2010):A vállalati stratégia, stratégiai terv pp.19-56 In:A stratégiai és üzleti tervezés gyakorlata.(Szerk. Nábrádi A.-Pupos T.)Szaktudás Kiadó Ház, Budapest,27p.ISBN 978-963-993540-2

[19] Nábrádi. A. szerk. (2019) A stratégiai tervezés XXI. századi gyakorlata, Partiumi Keresztény Egyetem, kézirat.

[20] O'Regan, N., Sims, M. A., \& Gallear, D. (2008).Leaders, loungers, laggards, the strategic planningenvironment performance relationship re-visited in manufacturing SMEs. Journal of Manufacturing Technology Management, $\quad$ 19(1), 21.http://dx.doi.org/10.1108/17410380810843426

[21] Phelps, R., Chan, C., \& Kapsalis, S. C. (2001). Does scenario planning affect performance? Two exploratory studies. Journal of Business Research, 51, 223232.http://dx.doi.org/10.1016/S0148-2963(99)00048-X

[22] Porter M.E. (1985), Competitive Advantage, The Free Press, New York

[23] Porter, M. E. (2006): Versenystratégia. Akadémia Kiadó, Budapest, pp.41-344. ISBN 963-05-83496

[24] Rumelt, R. - Chendel, D. - Teece, T.J. (1991): Strategic Management and Economics. Strategic Management Journal, Vol.: 12, Issue:2, 5-29.p.

[25] Spillan, J. E., \& Ziemnowicz, C. (2003). Strategic management in small retail businesses: the case of Guatemala. International Small Business Journal, 21(4), 461-478

[26] Sun Tzu, (BC.4. century): The Art of War

[27] Whittington, R. (2001): What is strategy - and does it matter? Cengage Learning, London. ISBN 978-1-86152-377-8 
[28] Wright, P., Kroll, M., Pray, B., \& Lado, A. (1995). Strategic orientation, competitive advantage, and business performance. Journal of Business Research, 33, 143151.http://dx.doi.org/10.1016/0148-2963(94)00064-L 